\title{
PENGEMBANGAN BUKU CERITA BERGAMBAR TENTANG MITIGASI BENCANA ERUPSI GUNUNG API UNTUK SISWA SD
}

\author{
Eni Suryaningsih ${ }^{1)}$, Laila Fatmawati ${ }^{2}$ \\ Fakultas Keguruan dan Ilmu Pendidikan Universitas Ahmad Dahlan Yogyakarta \\ e-mail: ${ }^{1}$ enisurya258@gmail.com; ${ }^{2}$ lailaokyfatmawati@gmail.com
}

\begin{abstract}
The background of this research is fact in the field regarding low knowledge of the community about disaster mitigation. Besides, there is no knowledge material presentation about volcano eruption disaster mitigation that routinely scheduled at schools in disaster prone areas. A media is needed to deliver knowledge material about mitigation and can be integrated in learning. This research aims to develop and determine the feasibility of picture story books about volcano eruption disaster mitigation for elementary school students in disaster prone areas. This is a Research and Development which carried out eight stages. The result of the assessments from the media expert is 85.33 (very good), material expert is 89.6 (very good), language expert is 76 (good), product test is 95.08 (very good), and application test is 88.66 (very good). All assessments average score is 86.93 converted into qualitative data is in the category of "Very Good".
\end{abstract}

Keywords: disaster mitigation, story book of disaster mitigation

\section{PENDAHULUAN}

Indonesia merupakan salah satu negara yang mendapat predikat negara rawan bencana. Indonesia adalah negara kepulauan dengan potensi bencana alam sangat tinggi khususnya gempa bumi, letusan gunung api dan tsunami, karena terletak pada tiga pertemuan lempeng bumi. Ketiga lempeng tersebut adalah lempeng Indo-Australia, lempeng Eurasia, dan lempeng Pasifik. Lempeng benua Eurasia yang memanjang dari pantai barat Sumatera hingga pantai selatan Jawa, terus ke timur sampai daerah Nusa Tenggara (Nur, 2010: 67) tersebut tertabrak oleh lempeng Indo-Australia dan menyusup ke bawah lempeng Eurasia, sehingga penunjaman lempeng tersebut mengakibatkan adanya jalur gempa bumi dan rangkaian gunung api aktif.

Wilayah Indonesia yang dilalui dua jalur pegunungan aktif di dunia yaitu sirkum pasifik dan sirkum mediterania mengakibatkan Indonesia memiliki banyak gunung api yang terletak di daerah Sumatra, Jawa hingga Nusa Tenggara. Selain itu Indonesia termasuk wilayah yang selalu bergerak, hal ini dapat dilihat dari jumlah gunung yang terdapat di Indonesia, ada 500 gunung api tidak aktif dan 129 gunung api yang masih memperlihatkan aktifitasnya (Basyid, 2009). Banyaknya gunung api yang terdapat di Indonesia mengakibatkan tanah Indonesia menjadi subur. Daerah yang mempunyai tanah subur menjadi salah satu pilihan untuk dijadikan tempat tinggal oleh masyarakat, karena masyarakat dapat memenuhi kebutuhan dengan bercocok tanam. Selain itu, secara budaya dan alami, tempat lahir dan dibesarkan memang mempunyai daya ikat yang kuat secara emosional dan kultural (Suhardjo, 2011) sehingga banyak penduduk yang memilih atau dengan sengaja tinggal di kawasan yang rentan terhadap bencana. Seperti halnya masyarakat yang tinggal di sekitar gunung api, mereka akan tetap tinggal di sana meski 
bahaya letusan gunung api dapat terjadi kapan saja

Aktivitas gunung api yang fenomenanya cenderung dapat diprediksi, menjadikan pentingnya memberikan pemahaman kepada masyarakat terkait mitigasi bencana gunung api. Mitigasi dapat diartikan sebagai upaya atau tahapan mengambil tindakan-tindakan untuk mengurangi pengaruh/ resiko dari suatu bahaya sebelum bahaya tersebut terjadi (Nirmalawati, 2011).

Upaya pemerintah dalam memberikan pemahaman kepada masyarakat tentang mitigasi bencana, salah satunya adalah melalui Lembaga Pusat Vulkanologi Mitigasi Bencana Geologi (PVMBG) serta Badan Penanggulangan Bencana Daerah (BPBD). Namun penyuluhan maupun soaialisasi tentang mitigasi tersebut dirasa masih kurang, sehingga masih banyak masyarakat yang belum mengetahui tentang mitigasi bencana. Salah satu peristiwa bencana yang mengakibatkan banyak korban adalah erupsi gunung Merapi tahun 2010, dengan kerusakan dan kerugian diperkirakan mencapai 2,1 trilyun rupiah dan korban meninggal 227 jiwa (Lestari, dkk, 2012).

Gunung merapi merupakan salah satu gunung api teraktif di dunia, karena hampir setiap periode mengalami erupsi. Periode berulang aktivitas erupsi berkisar 2-7 tahun (Susilo \& Rudiarto, 2014). Dampak dari erupsi gunung Merapi yang terletak di antara 4 kabupaten tersebut sangat dirasakan oleh masyarakat yang tinggal di daerah sekitar gunung. Empat Kabupaten yang dimaksud adalah Kabupaten Magelang, Kabupaten Sleman, Kabupaten Boyolali dan Kabupaten Klaten (BNPB, 2010).

Menurut peta wilayah zona ancaman Merapi yang bersumber dari BNPB (2010), Kecamatan Dukun Kabupaten Magelang termasuk salah satu wilayah dalam zona ancaman Merapi, yaitu jarak radius $15 \mathrm{~km}$ dari puncak Merapi. Beberapa kelurahan di kecamatan Dukun ada yang hanya berjarak 5 sampai $10 \mathrm{~km}$ dari puncak Merapi, salah satunya adalah Desa Ngargomulyo dan Desa Kalibening yang terletak di sebelah barat gunung Merapi. SD Negeri Ngargomulyo dan MI Muhammadiyah Kalibening adalah salah satu sekolah yang berada di kelurahan tersebut dan masuk dalam Sekolah Siaga Bencana.

Kurangnya pemahaman masyarakat dan orang tua tentang pengetahuan mitigasi bencana berdampak pada ketidak tahuan anak-anak mereka terhadap arti mitigasi bencana. Masyarakat baru menyadari setelah terjadi bencana, yang menyebabkan banyak korban harta, benda dan jiwa. Oleh karena itu perlu dirancang media yang berisi materi tentang mitigasi dan dapat digunakan sebagai suplemen dalam pembelajaran guna memperluas pengetahuan siswa tentang mitigasi bencana.

Dalam kenyataan di lapangan, masih banyak sekolah di kawasan rawan bencana yang belum memasukkan mitigasi bencana ke dalam program persekolahan. Guru yang mengajar di sekolah yang berada di kawasan rawan bencana tersebut belum mengembangkan media tentang mitigasi bencana, termasuk media dalam bentuk buku cerita bergambar sebagai suplemen dalam pembelajaran IPS. Keterbatasan tersebut membuat sedikit sekali guru mensosialisasikan atau mengajarkan mitigasi kepada siswa disekolah.

Pendidikan memiliki peran penting dalam kehidupan manusia, oleh karena itu pengetahuan tentang mitigasi dapat disampaikan melalui pendidikan, baik pendidikan formal maupun non formal. Penyelenggaraan pendidikan oleh sekolah 
seharusnya bukan hanya sekedar memberikan transfer pengetahuan melainkan dapat menjadikan belajar bermakna. Pembelajaran akan menjadi lebih bermakna ketika siswa terlibat secara aktif dalam menemukan konsep dari fenomena yang ada di lingkungan (Rizal: 2014), apalagi jika ditambah dengan pengetahuan dan pengalaman yang dimiliki oleh siswa. Selain belajar bermakna, belajar juga diharapkan dapat memberikan keterampilan kepada siswa.

Mitigasi bencana merupakan salah satu bagian dari keterampilan untuk kehidupan siswa, khususnya siswa yang bertempat tinggal di daerah rawan bencana, karena mitigasi bencana termasuk bagian dari keterampilan yang dapat diaplikasikan dalam kehidupan siswa. Hal ini sesuai dengan prinsip umum pengembangan kurikulum. Kurikulum yang dikembangkan disekolah hendaknya disesuaikan dengan tuntutan, kebutuhan dan perkembangan masyarakat (Syaodih: 2013: 150). Pembelajaran dapat disesuaikan dengan kebutuhan lingkungan, maka dari itu materi tentang mitigasi bencana dapat dijadikan salah satu materi muatan lokal, untuk sekolah dasar yang berada di daerah rawan bencana.

Siswa sekolah dasar merupakan peserta didik yang paling cepat menangkap dan mentransfer ilmu yang diperoleh dari sekolah untuk keluarga dan masyarakat. Oleh karena itu, pendidikan mitigasi sejak dini kepada siswa sekolah dasar merupakan suatu langkah awal untuk membangun masyarakat yang tanggap dan sadar bencana (Arifianti, 2011).

Siswa pada usia SD cenderung lebih senang membaca jika isi buku terdapat gambar yang menarik, bahkan lebih senang untuk membaca buku cerita bergambar (Rahmawati, 2016: 127). Buku cerita bergambar adalah sebuah cerita ditulis dengan gaya bahasa ringan, cenderung dengan gaya obrolan, dilengkapi dengan gambar yang merupakan kesatuan dari cerita untuk menyempaikan gagasan tertentu (Faizah, 2009: 253). Selain menarik, buku cerita bergambar juga mempunyai beberapa manfaat, diantaranya adalah dapat membantu perkembangan emosi anak, memperoleh kesenangan, membantu anak belajar tentang dunia dan untuk menstimulasi imajinasi (Nurgiantoro, 2015).

Media buku cerita bergambar tentang mitigasi bencana untuk sekolah dasar belum banyak dikembangkan, sehingga menjadikan penelitian ini mempunyai keunggulan tersendiri, yaitu dengan mengembangkan buku cerita bergambar tentang mitigasi bencana erupsi gunung api yang dapat terintegrasi dalam pembelajaran IPS. Sapriya (2011: 7) berpendapat bahwa pendidikan IPS terdapat dalam dua jenis, yakni pendidikan IPS untuk persekolahan dan pendidikan IPS untuk perguruan tinggi. Pendapat tersebut dapat diartikan bahwa pendidikan IPS penting untuk di ajarkan mulai dari sekolah dasar.

Berdasarkan uraian diatas maka peneliti terdorong untuk mengembangkan karakter tanggap bencana sejak dini melalui pengembangan buku cerita bergambar. Tujuan penelitian ini adalah untuk mengetahui bagaimana langkah-langkah pengembangan buku cerita bergambar, serta untuk mengetahui kualitas dan kelayakan buku cerita bergambar tentang mitigasi bencana erupsi gunung api untuk siswa SD/MI kelas IV di daerah rawan bencana.

\section{METODE PENELITIAN}

Jenis penelitian ini menggunakan metode penelitian dan pengembangan (Research and Development). Pengembangan dilakukan mengacu pada model pengembangan 
Sugiyono (2013: 201) dan hanya dibatasi sampai pada langkah ke delapan. Produk yang dikembangkan adalah buku cerita bergambar tentang mitigasi bencana erupsi gunung api untuk siswa SD/MI kelas IV di daerah rawan bencana. Penelitian dilaksanakan di SD Negeri Ngargomulyo dan MI Muhammadiyah Kalibening.

Uji coba dilakukan untuk mengumpulkan data yang dibutuhkan sebagai acuan untuk menentukan kelayakan kualitas buku cerita bergambar yang dikembangkan. Uji coba yang dilakukan meliputi uji validasi ahli, uji coba kelompok kecil dan uji coba kelompok besar.

Subjek coba dalam penelitian ini terdiri dari subjek uji ahli (ahli materi, ahli media dan ahli bahasa) yaitu dosen PGSD yang berkompeten di bidangnya. Uji coba kelompok kecil dilakukan terhadap 6 siswa di SD Negeri Ngargomulyo, sedangkan uji coba kelompok besar dilakukan terhadap 16 siswa di MI Muhammadiyah Kalibening.

Teknik pengumpulan data yang digunakan dalam penelitian dan pengembangan ini antara lain penilaian ahli, penilaian guru dan respon siswa. Dalam penelitian ini terdapat dua jenis data yang diperoleh peneliti, yaitu data kualitatif dan data kuantitatif. Data kualitatif dalam penelitian ini berupa saran dan masukan dari ahli dan guru yang diperoleh dari hasil validasi dan uji coba. Sedangkan data kuantitatif diperoleh dari hasil uji kelayakan produk yang diperoleh dari jumlah penilaian validasi ahli, guru dan siswa yang berupa skor dan selanjutnya dikategorikan menjadi kategori tertentu.

Instrumen pengumpulan data yang digunakan adalah kuesioner atau angket. Angket dalam penelitian ini menggunakan skala Likert yang mempunyai kategori rentang nilai mulai dari yang tertinggi sampai terendah (Suharsimi dan Cepi, 2009: 35). Peneliti menggunakan beberapa angket, diantaranya angket untuk ahli materi, ahli media, ahli bahasa, angket penilaian guru dan angket respon siswa.

Data yang diperoleh melalui lembar penilaian produk dianalisis secara kuantitatif dan kualitatif. Data kualitatif diperoleh dari: 1) komentar dan saran yang diperoleh dari ahli materi, media dan bahasa; 2) komentar dan saran dari guru kelas IV; 3) komentar dan saran dari siswa. Data yang diperoleh dianalisis dan dideskripsikan secara kualitatif untuk merevisi produk yang dikembangkan.

Data kuantitatif dalam penelitian dan pengembangan ini berupa: 1) skor penilaian dari validasi ahli; 2) skor dari uji coba produk; 3) skor dari uji coba pemakaian. Data angket respon siswa diukur menggunakan skala Guttman.

Dengan demikian, hasil penilaian ahli, uji coba produk serta uji coba pemakaian jika diperoleh hasil akhir minimal "Baik", maka produk buku cerita bergambar yang dikembangkan dapat dikatakan layak untuk digunakan.

\section{HASIL DAN PEMBAHASAN}

Buku cerita bergambar yang dikembangkan ini didasarkan pada permasalahan yang ditemukan peneliti, yaitu kurikulum yang digunakan sebagai acuan untuk proses kegiatan belajar belum dapat memfasilitasi upaya pemahaman materi tentang mitigasi bencana. Buku cerita bergambar yang dikembangkan merupakan bahan ajar tambahan berupa cerita bergambar yang memuat materi tentang mitigasi bencana erupsi gunung api yang disusun berdasarkan kurikulum untuk kelas IV SD/MI. 
Buku cerita bergambar tentang mitigasi bencana erupsi gunung api ini dirasa sangat sangat perlu untuk dikembangkan, mengingat secara geografis banyak sekolah yang berada pada kawasan rawan bencana. Seperti beberapa sekolah di Kecamatan Dukun Kabupaten magelang yang termasuk dalam zona ancaman Merapi (BNPB, 2010).

Kelebihan dari buku cerita bergambar yang mudah dimanfaatkan dan dapat digunakan dalam banyak hal untuk jenjang pengajaran (Sudjana \& Rivai, 2013) diharapkan dapat membuat siswa lebih tertarik untuk belajar tentang mitigasi. Selain itu buku cerita bergambar dapat merangsang imajinasi dan membantu anak dalam memperkaya imajinasi, karena gambar dalam buku cerita mengandung cerita (Nurgiyantoro, 2010: 154).

Buku cerita bergambar tentang mitigasi bencana erupsi gunung api diharapkan dapat menumbuhkan rasa gemar membaca pada siswa. Tujuan lainya adalah agar siswa mengetahui dan memahami pesan-pesan positif yang terkandung di dalamnya, serta dapat mengaplikasikan rangkaian upaya mitigasi bencana erupsi gunung api dalam kehidupan nyata.

Pengembangan buku cerita bergambar ini menggunakan desain pengembangan yang terdiri dari 10 langkah yaitu:, potensi dan masalah, pengumpulan data, desain produk, validasi produk, revisi desain, uji coba produk, revisi produk, uji coba pemakaian. Namun, pada penelitian ini dimodifikasi menjadi 8 langkah, yaitu sampai pada uji coba pemakaian karena keterbatasan peneliti untuk melaksanakan sampai langkah produksi masal (Sugiyono, 2013: 407) (Purwanto, 2014).

Melalui materi mitigasi bencana erupsi gunung api, siswa diajak untuk mengenal karakteristik lingkungan tempat tinggalnya, serta dilatih untuk waspada dan siap siaga apabila terjadi bencana

Pada proses pengembangan buku cerita bergambar ini terdapat beberapa tahapan. Tahap yang pertama, potensi dan masalah yaitu dilakukan pengamatan dari hasil wawancara pada tanggal 25 dan 27 Oktober 2016. Dari wawancara di dapatkan informasi sebagai berikut:

1. Pendidikan mitigasi belum masuk dalam program persekolahan.

2. Belum dikembangkan materi dan bahan ajar tentang mitigasi bencana erupsi gunung api.

3. Materi mitigasi bencana erupsi gunung api disampaikan melalui pelajaran IPS dan sifatnya masih terlalu umum.

4. Materi tentang mitigasi bencana erupsi gunung api dianggap perlu disampaikan kepada siswa, khususnya di daerah rawan bencana seperti daerah rawan gunung merapi.

Tahap yang kedua pengumpulan data, peneliti melakukan analisis kebutuhan siswa tentang perlu tidaknya pengembangan buku cerita bergambar tentang mitigasi bencana erupsi gunung api untuk siswa SD/MI di daerah rawan bencana. Selain itu peneliti melakukan analisis kurikulum, yaitu analisis silabus agar materi tidak menyimpang dengan SK dan KD yang telah ditetapkan. Berdasarkan wawancara dengan guru kelas dan kepala sekolah yang akan dijadikan sebagai tempat untuk penelitian, didapatkan informasi bahwa belum dikembangkan materi tentang mitigasi bencana erupsi gunung api yang terintegrasi dalam pembelajaran. Peneliti juga melakukan studi literatur, yaitu mencari beberapa teori yang akan dijadikan pijakan dalam pengembangan produk. 
Dari hasil studi pendahuluan pada tahap potensi dan masalah dapat disimpulkan bahwa guru belum mengembangkan materi dan media yang berkaitan dengan mitigasi bencana erupsi gunung api. Oleh karena itu, penelitian ini difokuskan untuk mengembangkan media buku cerita bergambar tentang mitigasi bencana erupsi gunung api untuk sekolah yang bberada di daerah rawan bencana.

Tahap ketiga adalah desain produk, pada tahap ini dilakukan pembuatan desain produk yang akan dikembangkan. Adapun langkahlangkah dalam mendesain produk yang dikembangkan adalah sebagai berikut:

1. Menganalisis kompetensi dasar, indikator dan tujuan pembelajaran pada materi yang akan dikembangkan

2. Menyusun materi dan mengintegrasikan materi tentang mitigasi bencana erupsi gunung api

3. Setelah selesai menyusun materi, mulai dilakukan pembuatan story board untuk memudahkan perancangan, dimana pembuatan gambar dilakukan dengan menggunakan aplikasi corel draw.

Setelah desain selesai dilakukan, kemudian dilanjutkan dengan pengembangan produk. Pada tahap pengembangan dilakukan beberapa kegiatan (Prihatina, 2016), diantaranya adalah sebagai berikut:

1. Perumusan ide, tokoh, alur dan pembentukan karakter

2. Pembuatan sketsa/ story board

3. Pembuatan desain/ ilustrasi gambar dengan Corel Draw

4. Pemberian teks dan dialnjutkan dengan mencetak produk.

5. Mencetak desain buku cerita bergambar yang telah dibuat, menggunakan kertas A5, jenis kertas ivory 230 gr untuk sampul dan art paper ukuran 120 gr untuk isi

Tahap ke empat adalah penilaian dan evaluasi. Penilaian yang pertama adalah penilaian oleh ahli, yaitu ahli materi, ahli media dan ahli bahasa. Setelah mendapat penilaian dari ahli selanjutnya dilakukan revisi berdasarkan saran dan masukan.

Berdasarkan uji validasi yang telah dilakukan oleh ahli materi, nilai yang didapatkan adalah dengan jumlah skor 112 . Sehingga dapat diketahui bahwa nilai yang didapat adalah 89,6. Apabila di konversikan ke dalam data kualitatif, maka nilai yang di dapat termasuk dalam kategori "Baik Sekali".

Berdasarkan uji validasi yang telah dilakukan oleh ahli media, nilai yang didapatkan adalah dengan jumlah skor 64 . Sehingga dapat diketahui bahwa nilai yang didapat adalah 85,33. Apabila di konversikan ke dalam data kualitatif, maka nilai yang di dapat termasuk dalam kategori "Baik Sekali".

Berdasarkan uji validasi yang telah dilakukan oleh ahli bahasa, nilai yang didapatkan adalah dengan jumlah skor 38 . Sehingga dapat diketahui bahwa nilai yang di dapat adalah 76. Apabila dikonversikan ke dalam data kualitatif, maka nilai yang di dapatkan termasuk dalam kategori "Baik".

Hasil respon angket siswa dalam uji coba produk (uji coba kelompok kecil) terhadap buku cerita bergambar dapat dilihat pada tabel 2. Hasil perhitungan respon siswa pada uji coba kelompok kecil menunjukkan nilai 96,42 kemudian dikonversikan ke dalam data kualitatif, berdasarkan nilai tersebut dapat disimpulkan bahwa buku cerita bergambar tentang mitigasi bencana erupsi gunung api termasuk dalam kategori "Baik Sekali". 
Tabel 2. Data hasil angket respon siswa (uji coba kelompok kecil)

\begin{tabular}{ccc}
\hline No & Nama & $\begin{array}{c}\text { Jumlah Jawaban Ya } \\
\text { (Skor) }\end{array}$ \\
\hline $1 . \quad$ Glh & 14 \\
$2 . \quad$ Uln & 12 \\
$3 . \quad$ Zk & 14 \\
$4 . \quad$ Isn & 14 \\
$5 . \quad$ Fnd & 13 \\
$6 . \quad$ Srs & 14 \\
\hline Jumlah & $\mathbf{8 1}$ \\
Nilai & $\mathbf{9 6 , 4 2}$ \\
Kategori & Baik Sekali \\
\hline
\end{tabular}

Hasil perhitungan penilaian guru pada uji coba kelompok kecil menunjukkan nilai 93,75 kemudian dikonversikan ke dalam data kualitatif, berdasarkan nilai tersebut dapat disimpulkan bahwa buku cerita bergambar tentang mitigasi bencana erupsi gunung api termasuk dalam kategori "Baik Sekali".

Seluruh nilai yang didapat dari angket respon siswa dan penilaian guru kemudian dicari rata-rata. Apabila nilai tersebut dikonversikan ke dalam data kualitatif maka penilaian buku cerita bergambar tentang mitigasi bencana erupsi gunung api dalam uji coba kelompok kecil termasuk dalam kategori "Baik Sekali".

Pada tahap uji coba pemakaian sebagai produk akhir bertujuan untuk melihat kelayakan dari buku cerita bergambar. Penilaian uji coba pemakaian di dapat melalui pengisian angket respon siswa kelompok besar dan angket penilaian guru yang dilakukan oleh guru kelas IV MI Muhammadiyah Kalibening, yaitu Daryanto, S.Pd. Adapun hasil data pada uji coba pemakaian adalah sebagai berikut:

Hasil penilaian angket Respon Siswa dalam uji pemakaian (uji coba kelompok besar) adalah sebagai berikut:
Tabel 3. Hasil Data Angket Respon Siswa (Uji Coba Pemakaian Kelompok Besar)

\begin{tabular}{lcc}
\hline No & Nama siswa & $\begin{array}{c}\text { Jumlah Jawaban Ya } \\
\text { (Skor) }\end{array}$ \\
\hline 1. & Zhr & 14 \\
2. & And & 14 \\
3. & Aml & 14 \\
4. & Nbl & 14 \\
5. & Rfk & 13 \\
6. & Nva & 14 \\
7. & Imm & 13 \\
8. & Aul & 14 \\
9. & Frl & 14 \\
10 & Dka & 14 \\
11. & Mwn & 13 \\
12. & Dms & 14 \\
13. & Tgr & 14 \\
14. & Frh & 13 \\
15. & Hfd & 11 \\
16. & Abd & 14 \\
\hline Jumlah & & $\mathbf{2 1 8}$ \\
Nilai & & $\mathbf{9 7 , 3 2}$ \\
Kriteria & & Sangat Baik \\
\hline
\end{tabular}

Tabel 3. adalah hasil respon siswa terhadap buku cerita bergambar, diketahui skor yang diperoleh sebanyak 218 sehingga nilai yang diperoleh nilai 97,32 kemudian dikonversikan ke dalam data kualitatif, berdasarkan nilai tersebut dapat disimpulkan bahwa buku cerita bergambar tentang mitigasi bencana erupsi gunung api termasuk dalam kategori "Baik Sekali”.

Hasil penilaian guru terhadap buku cerita bergambar, diketahui skor diperoleh sebanyak 75 sehingga hasil perhitungan penilaian guru pada uji coba kelompok besar menunjukkan nilai 80 kemudian dikonversikan ke dalam data kualitatif, berdasarkan nilai tersebut dapat disimpulkan bahwa buku cerita bergambar tentang mitigasi bencana erupsi gunung api termasuk dalam kategori "Baik Sekali".

Seluruh nilai yang didapat dari angket respon siswa dan penilaian guru kemudian 
dicari rata-rata. Apabila nilai tersebut dikonversikan ke dalam data kualitatif maka penilaian buku cerita bergambar tentang mitigasi bencana erupsi gunung api dalam uji coba kelompok besar termasuk dalam kategori "Baik Sekali".

Tahapan selanjutnya adalah analisis data, yang dilakukan setelah uji coba. Yang pertama analisis data kualitatif, berupa komentar dan saran dari penilaian. Ahli materi memberikan komentar dan saran yang bersifat membangun untuk perbaikan produk yang dikembangkan. Saran dan komentar dari ahli materi adalah untuk perbaikan redaksi, penambahan glosarium dan profil penulis.

Ahli media memberikan komentar dan saran yang bersifat membangun untuk perbaikan produk yang dikembangkan. sebagai berikut; 1) Buku supaya dilengkapi dengan deskripsi singkat pada sampul belakang, dan ditambahkan profil penulis, 2) Potongan buku jangan sampai menghilangkan bagian teks pada cerita, 3) Sesuaikan pemilihan warna antara teks dengan background. Sedangkan ahli bahasa memberikan komentar yaitu tentang konsistensi penggunaan tanda baca dan penggunaan kosa kata/istilah yang lebih familiar. Hal ini sesuai dengan pendapat Kustandi \& Sudjipto (2013: 145) bahwa aspek bahasa termasuk dalam komponen yang harus diperhatikan dalam pengembangan media pembelajaran. Bahasa yang digunakan harus disesuaikan dengan karakter peserta didik, serta penggunaan istilah dan struktur kalimat harus jelas.

Analisis hasil uji coba produk kelompok kecil, guru dan siswa memberikan komentar atau saran terhadap produk yang dikembangkan. Adapun komentar dan saran dalam tahap uji coba produk adalah sebagai berikut: 1) Siswa tertarik dengan buku cerita yang dikembangkan, 2) Siswa menjadi lebih bersemangat untuk membaca cerita kaena gambar dalam cerita bagus dan menarik, 3) Penyajian materi bagus sehingga dapat mendorong minat dan motivasi siswa dalam belajar.

Analisis data uji coba pemakaian kelompok besar, siswa dan guru memberikan penilaian, saran dan kritik sebagai berikut; 1) Buku cerita bagus, menarik dan bahasa yang digunakan mudah dipahami, 2) Siswa antusias dan semangat dalam membaca buku cerita, 3) Buku cerita dapat memberikan motivasi belajar, 4) Buku cerita tepat dengan kondisi lingkungan sekolah yang berada di kawasan rawan bencana.

Analisis data kuantitatif dilakukan Setelah uji validasi, hasil validasi dapat diketahui bahwa buku cerita yang dikembangkan mendapatkan nilai sebagai berikut:

Tabel 4. Data Kuantitatif Hasil Uji Validasi

\begin{tabular}{clcc}
\hline No & Penilaian & Nilai & Kategori \\
\hline 1 & Ahli materi & 89,60 & Baik Sekali \\
2 & Ahli media & 85,33 & Baik Sekali \\
3 & Ahli bahasa & 76 & Baik \\
\hline & Jumlah & $\mathbf{2 5 0 , 9 3}$ & \\
& Rata-rata & $\mathbf{8 3 , 6 4}$ & Baik Sekali \\
\hline
\end{tabular}

Dari data pada tabel 4 dapat diketahui bahwa penilaian buku cerita bergambar oleh para ahli mendapat rata-rata 83,6 dan termasuk dalam kategori Baik Sekali dan dinyatakan layak untuk digunakan. Apabila dari keseluruhan nilai dalam diagram dicari maka diperoleh rata-rata sebesar 83, 64 .

Sedangkan dari data pada tabel 5 dapat diketahui bahwa penilaian buku cerita bergambar dalam uji coba mendapat rata-rata 91,87 dan termasuk dalam kategori "Baik Sekali". Apabila dari keseluruhan nilai uji 
coba dalam diagram dicari maka diperoleh rata-rata sebesar $91,87$.

Tabel 5. Data Kuantitatif Hasil Uji Coba

\begin{tabular}{clcc}
\hline No & \multicolumn{1}{c}{ Penilaian } & Nilai & Kategori \\
\hline 1 & Uji coba produk & & \\
& Angket respon & 96,42 & Baik \\
& siswa & & Sekali \\
& Penilaian guru & 93,75 & $\begin{array}{c}\text { Baik } \\
\text { Sekali }\end{array}$ \\
& & & \\
2 & Uji coba & & \\
& pemakaian & & \\
& Angket respon & 97,32 & Baik \\
& siswa & & Sekali \\
& Penilaian guru & 80,00 & Baik \\
& & & Sekali \\
\hline & Jumlah & $\mathbf{3 6 7 , 4 9}$ & \\
& Rata-rata & $\mathbf{9 1 , 8 7}$ & Baik \\
& & & Sekali \\
& &
\end{tabular}

Seluruh penilaian dari 3 ahli, angket respon siswa dan penilaian guru dari uji coba produk dan uji coba pemakaian terhadap buku cerita bergambar tentang mitigasi bencana erupsi gunung api dapat dicari rata-rata dengan menggunakan rumus yang sudah ditentukan diperoleh hasil sebesar 87,75

Berdasarkan nilai tersebut setelah dicari rata-rata maka nilai dari keseluruhan penilaian dari buku cerita bergambar tentang mitigasi bencana erupsi gunung api dikonversikan dan dapat disimpulkan dalam kategori "Baik Sekali”.

Buku cerita bergambar tentang mitigasi bencana erupsi gunung api yang dikembangkan berisi tentang upaya-upaya mitigasi bencana erupsi gunung api, atau langkah-langkah yang harus dilakukan ketika terjadi erupsi gunung api yang dikemas dalam bentuk cerita bergambar. Kalimat yang digunakan dalam buku cerita bergambar juga disesuaikan dengan anak usia SD, yaitu dengan bahasa yang tidak berbelit dan mudah dipahami (Sugiarti, 2015).
Buku cerita dilengkapi dengan gambargambar yang menarik agar siswa tertarik untuk membaca dan mempelajarinya. Hal ini sesuai dengan (Wahyuningsih, 2012) yang menyebutkan bahwa minat itu dapat timbul ketika peserta didik tertarik dengan sesuatu, dan sesuatu yang dibutuhkan atau dipelajari tersebut dapat bermakna bagi dirinya.

Buku cerita bergambar tentang mitigasi bencana erupsi gunung api ini dapat digunakan sebagai buku suplemen dalam pembelajaran IPS, serta dapat digunakan sebagai media pembelajaran tentang mitigasi bencana erupsi gunung api. Hal ini didukung dengan pendapat (Wahyuningsih, 2012) yang mengatakan bahwa media pembelajaran merupakan alat yang berfungsi untuk menyampaikan pesan pembelajaran.

Berdasarkan deskripsi data penilaian yang telah tersaji, buku cerita bergambar yang dikembangkan ini telah mendapatkan nilai dengan kategori sangat baik dan layak untuk digunakan. Buku ini dapat dijadikan sebagai salah satu sumber untuk mengajarkan mitigasi bencana erupsi gunung api sejak dini kepada siswa sekolah dasar, khususnya di sekolahsekolah yang berada di daerah rawan bencana.

\section{SIMPULAN DAN SARAN}

Setelah melalui beberapa tahapan dalam penelitian, produk buku cerita bergambar tentang mitigasi bencana erupsi gunung api telah selesai dikembangkan. Berdasarkan hasil penelitian dan pembahasan maka dapat diambil kesimpulan sebagai berikut:

Telah dikembangkan buku cerita bergambar tentang mitigasi bencana erupsi gunung api untuk siswa SD/MI kelas IV di daerah kawasan rawan bencana melalui 8 tahap pengembangan. Produk yang dikembangkan berbentuk buku cerita bergambar yang telah diuji validasi oleh dosen 
ahli materi, ahli media dan ahli bahasa. Dinilai oleh 6 siswa kelas IV SD Negeri Ngargomulyo, 16 siswa MI Muhammadiyah Kalibening serta guru kelas IV dari kedua sekolah tersebut.

Pengembangan buku cerita bergambar tentang mitigasi bencana erupsi gunung api disusun dengan menerapkan model pengembangan Sugiyono (2013: 201). Langkah analisis meliputi analisis kurikulum, analisis karakteristik siswa dan materi. Tahap perancangan dilaksanakan dengan menyusun materi dan pembuatan story board. Pada tahap pengembangan dilaksanakan pengembangan buku cerita kemudian dilanjukan pada tahap mencetak desain. Hasil validasi dari ahli menunjukkan tingkat kelayakan sangat baik dan buku cerita tersebut dapat diujicobakan dengan revisi. Uji coba kelompok kecil dilakukan terhadap 6 siswa, sedangkan pada uji coba kelompok besar dilakukan pada 16 siswa yang diambil secara acak.

Kelayakan buku cerita bergambar tentang mitigasi bencana erupsi gunung api berdasarkan penilaian tiga dosen ahli, masingmasing mendapatkan nilai sebagai berikut, 89,6 dari ahli materi, 85,33 dari ahli media, 76 dari ahli bahasa, 95,08 pada uji coba kelompok kecil dan 88,6 pada uji coba kelompok besar. Apabila diambil nilai ratarata dari uji validasi mendapatkan nilai 83,64, dan nilai rata-rata dari uji coba produk mendapatkan nilai 91,87. Dengan demikian buku cerita bergambar tentang mitigasi bencana erupsi gunung api untuk siswa SD/MI kelas IV di daerah rawan bencana layak untuk digunakan.

Saran yang dapat disampaikan berdasarkan penelitian ini dalam rangka mengembangkan bahan ajar serta media khususnya buku cerita adalah, buku cerita bergambar tentang mitigasi bencana erupsi gunung api yang dihasilkan dapat dikembangkan dengan cerita yang berbeda, ataupun materi mitigasi bencana yang lainya. Selain itu dapat digunakan sebagai bahan ajar untuk siswa sekolah dasar dan pendidikan selanjutnya terkait dengan pembelajaran mitigasi bencana sejak dini. 


\section{DAFTAR PUSTAKA}

Arifianti, Y. (2011). Buku Mengenal Tanah Longsor Sebagai Media Pembelajaran Bencana Sejak Dini. Bulletin Vulkanologi dan Bencana Geologi, 6(3), 17-24.

Arikunto, Suharsimi \& Sarifudin Cepi. (2009). Evaluasi Program Pendidikan. Jakarta: Bumi Aksara.

Basyid, A. (2010). Pengembangan Peta Rencana Kontijensi Bencana Gunung Api. Jurnal Itenas Rekayasa, 14(4), 216-226.

BNPB. (2010). "Peta Zona Ancaman Merapi”. http://geospasial.bnpb.go.id/wpcontent/uploads/2010/11/2010-11-15_update_zonasi_ancaman_merapi_bnpb.pdf. (di akses tanggal 12 Oktober 2017)

Faizah, U. (2009). "Keefektifan cerita bergambar untuk pendidikan nilai dan keterampilan berbahasa dalam pembelajaran Bahasa Indonesia”. Jurnal Cakrawala Pendidikan, 3(3), 249-256.

Lestari, P., Prabowo, A., \& Wibawa, A. (2012). "Manajemen Komunikasi Bencana Merapi 2010 pada saat Tanggap Darurat". Jurnal Ilmu Komunikasi UPN Veteran Yogyakarta, 10(2), 173-197.

Nirmalawati, N. (2012). Pembentukan Konsep Diri Pada Siswa Pendidikan Dasar Dalam Memahami Mitigasi Bencana. SMARTek, 9(1), 61-69.

Nur, A. M. (2010). Gempa Bumi, Tsunami Dan Mitigasinya. Jurnal Geografi, 7(1), 66-73.

Nurgiyantoro, Burhan. 2005. Sastra Anak. Yogyakarta: Gadjah Mada University Press.

Prihatina, R. R. N. (2016). Pengembangan Media Pembelajaran Buku Cerita Bergambar untuk Pembelajaran IPS Siswa SMP Kelas VIII. Social Studies, 5(8), 1-10.

Purwanto, Ngalin. (2013). Prinsip-prinsip dan Teknik Evaluasi Pengajaran. Bandung: Remaja Rosdakarya.

Rahmawati, Aulia. (2016). Penerapan SQ3R Berbantuan Reka Cerita Gambar untuk Meningkatkan Pemahaman Membaca dan Hasil Belajar siswa. Profesi Pendidikan Dasar, Vol. 3, No. 2, hlm. 126-132

Rizal, M. (2014). Pengaruh Pembelajaran Inkuiri Terbimbing dengan Multi Representasi terhadap Keterampilan Proses Sains dan Penguasaan Konsep IPA Siswa SMP. Jurnal Pendidikan Sains, 2(3), 159-165.

Sapriya. (2011). Pendidikan IPS. Bandung: Rosdakarya.

Sudjana, Nana \& Ahmad Rivai. 2013. Media Pengajaran. Bandung: Sinar Baru Algensindo. 
Sugiarti, D. (2015). Pembuatan Buku Cerita Bergambar Dengan Tokoh Gatotkaca Sebagai Media Pembelajaran Kelas B TK Khalifah Surabaya. Jurnal Pendidikan Seni Rupa, 3(1), 64-69.

Sugiyono. (2013). Metode Penelitian Pendidikan Pendekatan Kuantitatif Kualitatif dan R\&D. Bandung: Alfabeta.

Suhardjo, D. (2011). Arti Penting Pendidikan Mitigasi Bencana Dalam Mengurangi Resiko Bencana. Jurnal Cakrawala Pendidikan, (2), 174-188.

Susilo, A. N., \& Rudiarto, I. (2014). Analisis Tingkat Resiko Erupsi Gunung Merapi Terhadap Permukiman di Kecamatan Kemalang, Kabupaten Klaten. Teknik PWK (Perencanaan Wilayah Kota), 3(1), 34-49.

Syaodih, Nana. 2013. Pengembangan Kurikulum. Bandung: PT Remaja Rosdakarya.

Wahyuningsih, A. N. (2012). Pengembangan Media Komik Bergambar Materi Sistem Saraf Untuk Pembelajaran Yang Menggunakan Strategi PQ4R. Journal of Innovative Science Education, 1(1), 20-27. 